\title{
BETONARME ELEMANLARDA DONATI KOROZYONUNUN FARKLI HIZLANDIRILMIŞ KOROZYON DENEY YÖNTEMLERİ ILE ARAŞTIRILMASI
}

\author{
Ahmet Raif BOĞA \\ Mustafa KOCER \\ Murat ÖZTÜRK
}

Alınma: 19.02.2020; düzeltme: 05.05.2020; kabul: 06.05.2020

Öz: Yapıların çeşitli sebeplerden dolayı maruz kaldığı korozyon, servis yüklerine göre tasarlanan yap1 elemanlarının yapısal performanslarını olumsuz bir șekilde etkilemektedir. Bu yüzden, servis ömrünü tamamlamaya yaklaşan mevcut yapı stoku düşünüldüğünde, yapısal bütünlüğü tehdit eden korozyonun etkilerinin araştııılması ve değerlendirilmesi oldukça büyük bir önem taşımaktadır. Literatürde yer alan çalışmalar incelendiğinde, hızlandırılmış korozyon deneylerinin hemen hemen hepsinin sabit voltaj altında uygulandığı görülmüsşür. Bu çalışmada, mevcut yapıları temsil etmesi için beton kalitesi yetersiz iki adet betonarme elaman üretilerek, numunelerin biri sabit akım altında diğeri sabit voltaj altında hızlandırılmış korozyon deneyine maruz bırakılmıștır. Deneyler sonucunda donatılarda oluşan gerçek ağırlık kayıpları belirlenmiştir. Gerçek ağırlık kayıplarının her iki yöntem için belirlenen teorik ağırlık kayıplarına, oldukça yakın olduğu görülmüştür. Ayrıca sabit akım ve voltaj altında hızlandırılmış korozyon deney düzeneğinin uygulanabilirliği, olumlu ve olumsuz yönleri karşılaştırmalı olarak yorumlanmıştır.

Anahtar Kelimeler: Betonarme eleman, Korozyon, Hızlandırılmış korozyon deneyi, Beton

\section{Investigation of Reinforcement Corrosion in Reinforced Concrete Elements with Different Accelerated Corrosion Test Methods}

\begin{abstract}
Corrosion that structures are exposed to for various reasons adversely affects the structural performance of the structural elements designed according to service loads. Therefore, considering the existing building stock approaching the end of its service life, it is very important to investigate and evaluate the effects of corrosion that threatens structural integrity. When the literature are examined, it is seen that almost all accelerated corrosion tests are performed under constant voltage. In this study, two reinforced concrete elements with insufficient concrete quality were produced to represent the existing structures; one of them was subjected to accelerated corrosion test under constant current and the other under constant voltage. As a result of the experiments, the actual weight losses in the reinforcements were determined. The experimental weight loss was found to be very close to the theoretical weight loss determined for both methods. Furthermore, the applicability, positive and negative aspects of accelerated corrosion test setup under constant current and voltage have been interpreted comparatively.
\end{abstract}

Keywords: Reinforced concrete element, Corrosion, Accelerated corrosion test, Concrete

\footnotetext{
* Afyon Kocatepe Üniversitesi, Mühendislik Fakültesi, İnşaat Mühendisliği Bölümü, 03200, Afyonkarahisar, Türkiye

*** Konya Teknik Üniversitesi, Mühendislik ve Doğa Bilimleri Fakültesi, İnşaat Mühendisliği Böl., Konya, Türkiye

İletişim Yazarı: Ahmet Raif BOĞA (araif@aku.edu.tr)
} 


\section{GÍRIŞ}

Türkiye Hazır Beton Birliği'nin Elâzı̆̆ Depremi İnceleme Raporu'nda yıkılan veya ağır hasar gören yapılardaki beton sınıflarının C6 ile C12 arasında değişmekte olduğu belirtilmiştir (http://www.thbb.org/teknik-bilgiler/raporlar/elazig-depremi/). Marmara depremi sonrasinda Bağcılar, Avcılar, Yalova, Gölcük ve Çınarcık'da göçen veya ağır hasar gören yapılardaki betonların karot basınç dayanımlarının 14 MPa'nın altında kaldığı bildirilmiştir. Ayrıca Bağcılar ve Avcılar'dan elde edilen ortalama karot basınç dayanımlarının sırasıyla 7,8 ve 7,7 $\mathrm{MPa}$ değerlerinde olduğu belirtilmiştir (Taşdemir ve diğ., 1999).

Marmara depremi sonrası Avcılar'da hasar görmüş 5 ayrı binadan alınan karot örnekleri üzerinde yapılan incelemeler sonucunda üretilen betonların $4 \mathrm{~mm}$ 'den geçen malzeme miktarlarının çok yüksek oranlarda olduğu görülmüştür. Yani beton üretimlerinde kum kullanımının bazı örneklerde \%70, 83 ve 91'e varan oranlarda olduğu anlaşılmıştır (Taşdemir ve diğ., 1999). Ayrıca Türkiye Hazır Beton Birliği'nin Elâzı̆̆ Deprem raporunda da yıkılan veya ağır hasar görmüş yapıların betonlarının agrega tane dağılımlarının uygun olmadığından bahsedilmiştir (http://www.thbb.org/teknik-bilgiler/raporlar/elazig-depremi/).

Agrega tane dağılımlarındaki bu uygunsuzluklardan dolayı beton kaliteleri düşmektedir. Depremde binaların zarar görmesinde beton kalitelerinin yetersiz olmasının önemli bir etkisinin olduğu belirtilmektedir. Beton kalitesi yetersiz ve daha boşluklu olan betonlar içerisindeki çelik donatıları koruyamamakta ve çelik donatılar korozyon problemi ile karşı karşıya kalmaktadırlar (Taşdemir ve diğ., 1999).

Betonarme yapıları servis ömürleri boyunca tehdit eden korozyon, donatıya verdiği tahribattan dolayı yapıların yanal yer değiştirme kapasitelerini kaybetmesindeki başlıca etkenlerden biri olarak gösterilmektedir (Göksu ve İlki, 2016). Meydana gelen yıkıcı depremler sonrası yapılan saha incelemeleri, yıkılan veya ağır hasar gören yapıların büyük bölümünde donatıların korozyona uğradığını ve beton ile donatı arasındaki aderansın kaybolduğunu göstermektedir (Ma ve diğ., 2012; Di Carlo ve di ̌̆., 2017). Korozyondan etkilenen yapıların hizmet ömrü, donatının beton örtüsünün kaybolması ile karakterize edilmektedir. Bu aşamadaki yapı, korozyon hasarına karşı daha korumasız olduğu için donatı ile beton arasındaki aderanstan, beton ve çeliğin mekanik özelliklerinden, donatının sahip olduğu en kesit alanından, sargı donatısı etkinliğinden söz etmek ve proje verilerini dikkate almak çok doğru olmamaktadır (Bousias ve diğ., 2002; Yang ve diğ., 2016; Rajput ve diğ., 2019). Ayrıca korozyon olayının oluşmas1, elemanlarda çatlamaya ve yüksek gerilmelere neden olmakta ve bu durum beton-donatı aderansını olumsuz etkilemektedir ( $\mathrm{Li}$ ve diğ., 2009; Liu ve diğ., 2017). Bunun yanında deprem sırasında yapı güvenliği açısından en kritik elemanların (özellikle bodrum kat) kolonlar olduğu bilinmektedir (Doğan, 2009). Bu nedenle, özellikle korozyona uğramış betonarme kolonların yatay yük altındaki davranışlarını ve alınabilecek önlemleri araştırmak, Türkiye gibi aktif deprem kuşağı içinde yer alan bir ülke için büyük önem taşımaktadır.

Hızlandırılmış korozyon deneylerinde, klorür iyonlarının betonarme elemanlara nüfus ettirilmesi de araştırmacılara göre farklılık göstermektedir. Göksu ve İlki (2016) çalışmalarında, beton karışım suyuna çimento ağırlığının \%4'ü kadar kalsiyum klorür $\left(\mathrm{CaCl}_{2}\right)$ ekleyerek, beton dökümünden sonra kolonu kauçuk ve çelik hasır ile sarmışlardır. Kolon boyuna ve enine donatılarına $6 \mathrm{~V}$ sabit bir voltaj uygulanarak, akımın yönü anot kutbu olan kolon donatılardan katot görevi gören çelik hasıra doğru olmuştur. Kauçuk ise büyük korozyon seviyeleri için beton yüzeyine püskürtülen $\mathrm{CaCl}_{2}$ çözeltisinin daha geç buharlaşmasını sağlamak amacıyla kullanılmıştır. Deney sırasında kolonlarda GECOR8 cihazı ile korozyon hızını ölçerek yarı hücre potansiyel yöntemiyle deney süresini belirlemişlerdir. Daha sonra donatıdan alınan örnekler yardımıyla ilk başta ağırlık kaybına bakmışlar, daha sonra elektronik mikroskop yardımıyla meydana gelen kesit kayıplarını belirlemişlerdir.

Meda ve diğ. (2014), sabit 0,5A'lik akım altında $\varnothing 500 \mathrm{~mm}$ çapındaki PVC boru içerisine $\% 3 \mathrm{NaCl}$ ekleyerek, emdirme metodu ile deney düzeneğini oluşturmuşlardır. Sabit amper altında 
istenilen korozyon seviyelerini elde etmek amaciyla beton örtülü ve beton örtüsüz çelik donatılar korozyon hasarına maruz bırakılarak oluşan gerçek kütle kaybı ile Faraday denkleminden hesap edilen teorik kütle kaybı karşılaştırılmıştır. Sonuçlara göre, referans numunedeki beton örtülü donatının, beton örtüsüz donatıya göre etkisini temsil etmesi için Faraday denklemine sabit bir katsayı çarpanı eklemişlerdir. Bu çarpan ile sabit amper değeri Faraday denkleminde yerine koyularak istenilen kütle kaybı miktarına göre üretilen üç adet betonarme numunenin hızlandırılmış korozyon deney süresini deneye başlamadan belirlemiş̧lerdir. Araştırmanın amacı doğrultusunda etriyeleri epoksi ile kaplayarak, boyuna donatılarda meydana gelen korozyonun yapı elemanının performansına etkisini, korozyon hasarı seviyesine göre belirlemişlerdir.

Yang ve diğ. (2016), hem marina bölgesinin iklim koşullarını yansıtmak, hem de sodyum klorürlü suyun yapı elemanlarına sıçrama olasılı̆̆ı olan durumları temsil etmesi amaciyla, emdirme yöntemi yerine sarma yöntemini kullanmışlardır. Beton yüzeyini önce süngerle sarmışlar, ikinci katman olarak sünger üstüne çelik hasır uygulamışlar ve son olarak çelik hasırın üstünden suyun hızlı bir şekilde buharlaşmasını engellemek amacıyla plastik bir film ile kaplamışlardır. Tuzlu su çözeltisini (\%3-5 oranına sahip), her iki saatte bir kolon üstündeki süngere deney süresi boyunca uygulamışlardır. Donatılar için teorik korozyon süresinin belirlenmesinde Faraday denklemini kullanmışlardır. Faraday denkleminde, kütle kaybında etriyenin etkisini de, dikkate almak için 1,25 katsayısı ile genişletmişlerdir. Dengelenmiş akım şiddetini 2,1 A alarak deney süresini belirlemişlerdir. Korozyon süreci, teorik korozyon miktarlarına ulaştıktan sonra deneye son vermişlerdir. Deneyler sonunda, \% 5, \% 10, \% 15 ve \% 20 olarak hedeflenen teorik ağılık kayıpları, \% 5,1, \% 8,3, \% 13,25, \% 16,8 olarak gerçekleşmiştir.

Yalçıner ve diğ. (2018), çalışmalarında yüksekliği $85 \mathrm{~cm}$, genişliği $175 \mathrm{~cm}$ boyutlarında olan tam ölçekli bir membran yalıtımlı betonarme paslandırma havuzu tasarlamışlardır. Ürettikleri tam ölçekli 6 adet betonarme kirişten biri referans olmak üzere, geriye kalan 5 adet betonarme kirişi emdirme yöntemiyle sabit $60 \mathrm{~V}$ akım altında hızlandırılmış korozyon deneyine tabi tutmuşlardır. Betonarme kirişlerin çekme donatılarına pozitif, havuzda yer alan bakır levhalara negatif yükleme yapacak şekilde dış akımı sabit voltaj şeklinde vererek, deney süresi boyunca akımları veri toplama cihazı vasıtasıyla kaydetmişlerdir. Deneylerden sonra kirişlerin her birinden çıkartılan donatılar tartılarak Faraday denklemi ile hesaplanan teorik ağırlık kayıpları ile karşılaştırmışlardır. Faraday denklemine göre kirişler için hedeflenen korozyon oranları sırasıyla, $\%$ 5,04, \% 9,23, \% 9,27, \% 12,18, \% 14,61 iken, gerçek ağırlık kayıpları sırasıyla \% 3,23, \% 5,13, $\%$ 5,38, \% 6,20,\% 9,0 olarak elde edilmiştir.

Literatür incelendiğinde, çeşitli araştırmacılar tarafindan korozyon hasarının yapı elemanları üzerine etkisini araştırmak için laboratuvar ortamında daha kısa sürelerde elektrokimyasal yöntemle yapay korozyon üretilmiştir. Elektrokimyasal yöntemle hızlandırılmış korozyon deneylerinde, klor iyonlarının donatıya nüfus ettirilmesi sargılama, emdirme ve beton karışım suyuna ekleme şekillerinde yapılmaktadır. Elektrokimyasal dış akım ise sabit voltaj ve sabit akım olmak üzere iki farklı yöntemle uygulanmaktadır.

$\mathrm{Bu}$ çalışmada, günümüz yapı stoğunda yer alan eski yapıların temsil edilebilmesi için eski yapıların agrega tane dağılımları ile benzerlik gösteren (agrega tane dağılımı düzgün olmayan) ve düşük dayanımlı beton tasarımı yapılmıştır. Bu betonlar ile üretilen 2 adet betonarme elemana laboratuvar şartlarında hızlandırılmış korozyon deneyi uygulanarak yapay korozyon üretilmiştir. Laboratuvar şartlarında yapay korozyonu üretmek için, biri sabit akım diğeri sabit voltaj altında çalışan iki ayrı deney düzeneği oluşturulmuştur. Hızlandırılmış korozyon deneyleri ardından, numunelerde yer alan donatılar çıkartılarak, gerçek ağırlık kayıpları belirlenmiştir. Çalışmanın temel amacı doğrultusunda, her iki elektrokimyasal dış akım altında meydana gelen gerçek ağırlık kayıplarının deneylerden önce Faraday Denklemi ile hesaplanan teorik ağırlık kayıpları ile yakınsaması karşılaştııılmıştır. Ayrıca donatılar üzerinde çekme deneyleri yapılarak donatıların akma, çekme ve şekil değiştirme yüzdelerindeki değişimler de incelenmiştir. 
Boğa A.R., Koçer M., Öztürk M.: Btnrme.Elmnlrda.Dntı.Krzyn.Frklı.Hzındrımış.Krzyn.Dny.Yntmlri.ile Arşt.

\section{MATERYAL VE METOT}

\subsection{Kullanılan Malzemeler}

\subsection{1. Çimento, Agregalar ve Uçucu Kül}

Afyon Çimento Fabrikası'nın üretmiş olduğu TS EN 197-1 standartlı CEM I 42,5 R Portland Çimentosu kullanılmıştır (TS EN 197-1, 2012). Çimentonun kimyasal ve fiziksel özelliklerine ait deney sonuçları, Tablo 1'de verilmiştir.

Afyon KOLSAN hazır beton tesisinin taş ocaklarından elde edilen kalker esaslı kırma kum (0-4 mm), kırma taş I (4-11,2 mm) ve kırma taş II (11,2-22,4 mm) agregaları kullanılmıştır. Kırma kum, kırma taş I ve kırma taş II agregalarının özgül ağırlıkları sırasıyla $2,67,2,70$ ve 2,70 olarak bulunmuştur.

Beton üretimlerinde Seyitömer Termik Santraline ait uçucu kül (UK) kullanılmıştır. Uçucu külün özgül ağırlığı 2,25 olarak elde edilmiştir. Ayrıca beton üretimlerinde süperakışkanlaştırıcı (SA) beton katkısı da kullanılmıştır.

Tablo 1. Çimentonun kimyasal ve fiziksel özellikleri

\begin{tabular}{|c|c|c|}
\hline & Kimyasal Bileşim, \% & CEM I 42,5 R \\
\hline \multirow{11}{*}{ 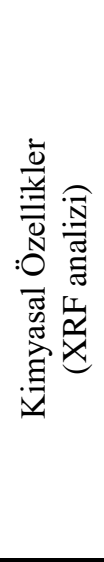 } & $\mathrm{SiO}_{2}$ & 18,97 \\
\hline & $\mathrm{Al}_{2} \mathrm{O}_{3}$ & 4,81 \\
\hline & $\mathrm{Fe}_{2} \mathrm{O}_{3}$ & 3,78 \\
\hline & $\mathrm{CaO}$ & 63,58 \\
\hline & $\mathrm{MgO}$ & 1,54 \\
\hline & $\mathrm{Na}_{2} \mathrm{O}$ & 0,15 \\
\hline & $\mathrm{K}_{2} \mathrm{O}$ & 0,55 \\
\hline & $\mathrm{SO}_{3}$ & 2,89 \\
\hline & $\mathrm{Cl}^{-}$ & 0,0113 \\
\hline & Kızdırma Kaybı & 3,23 \\
\hline & Çözünmeyen Kalıntı & 0,31 \\
\hline \multirow{4}{*}{ 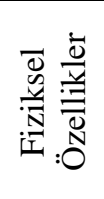 } & Özgül Ağırlık & 3,11 \\
\hline & Özgül Yüzey, $\mathrm{cm}^{2} / \mathrm{g}$ & 3819 \\
\hline & Priz Başlama Süresi, dk & 145 \\
\hline & Priz Bitiş Süresi, dk & 232 \\
\hline
\end{tabular}

\subsubsection{Celik Donatılar}

Betonarme numunelerin üretiminde 8 ve $16 \mathrm{~mm}$ çapında nervürlü $\mathrm{B} 420 \mathrm{C}$ betonarme çeliği kullanılmıştır.

\subsubsection{Sodyum Klorür Tuzu}

Betonarme numunelerin korozyon performanslarının belirlenmesi amacı ile yapılan hızlandırılmış korozyon deneylerinde sanayi tipi sodyum klorür tuzu kullanılmıştır. 


\subsection{Beton Karışım Oranları}

Yapılan çalışmada, üretilen betonarme numunelerinin hızlı bir şekilde korozyona uğratılabilmesi ve günümüz yapı stokunda yer alan eski yapıları temsil edebilmesi için düşük dayanımlı ve agrega tane dağılımı uygun olmayan beton tasarımı yapılmıştır. Yapılan tasarım ile beton sınıfının yaklaşık olarak $\mathrm{C} 12 / 15$ olmasına karar verilmiştir. Bu amaçla düşük oranda çimento dozajı kullanılmıştır. Su/bağlayıcı oranı 0,88 olarak seçilmiştir. Betonun karışım oranları Tablo 2'de verilmiştir.

Tablo 2. Beton karışım oranları, $\mathrm{kg} / \mathrm{m}^{3}$

\begin{tabular}{|c|c|c|c|c|c|c|c|}
\hline Karışım & Su & Çimento & Uçucu Kül & Kum & Kırmataş I & Kırmataş II & SA \\
\hline C12/15 & 185 & 150 & 60 & 1420 & 180 & 359 & 1,50 \\
\hline
\end{tabular}

\section{3. Üretilen Numune Tipleri, Kür Koşulu ve Süreleri}

\subsubsection{Beton numunelerinin üretimi, kür koşulu ve süreleri}

Betonların fiziksel ve mekanik özelliklerini belirlemek için 100x200 mm boyutlarında silindir ve 150x150x150 mm boyutlarında küp numuneler üretilmiştir. Beton döküm işlemi sırasında 28 ve 180 günlük kür süreleri için 3'er adet küp ve silindir numune alınmıştır. Toplamda 6 adet küp ve 6 adet silindir numune üretilmiștir. Üretilen beton numuneleri 24 saat laboratuvar ortamında kalıplarında bekletilmiş ve sonrasında kalıplarından çıkartılmıştır. Beton numunelerine 28. ve 180. güne kadar $20 \pm 2{ }^{\circ} \mathrm{C}$ sicaklığa sahip kirece doygun su havuzlarında standart kür uygulanmış ve sonrasında ultrases geçiş hızı, basınç ve yarmada-çekme dayanımı deneyleri yapılmıştır.

\subsubsection{Betonarme numunelerinin üretimi, kür koşulu ve süreleri}

Hızlandırılmış korozyon testine maruz bırakmak amacıyla 2 adet betonarme elaman imal edilmiştir. Üretilen betonarme numunelerin detayları Şekil 1'de gösterilmiştir. Konsol kısım dikdörtgen en kesitli olup kesit boyutları $20 \times 25 \mathrm{~cm}$ 'dir. Konsol kısmın yüksekliği $80 \mathrm{~cm}$ 'dir ve boyutları $60 \times 45 \times 30 \mathrm{~cm}$ olan bir temel ayağ donatı ve $\varnothing 8 / 10 \mathrm{~cm}$ 'lik enine donatı kullanılmıştır. Temel ayağı, alt ve üst eğilme donatısı $3 \varnothing 16$ ile kesme donatısı olarak $\varnothing 8 / 10 \mathrm{~cm}$ 'lik etriyelerle güçlendirilmiştir. Konsol bölümde paspay1 2 $\mathrm{cm}$, temel ayağının paspayı ise $5 \mathrm{~cm}$ olarak belirlenmiştir. Şekil 2a'da imal edilen numunelerin beton dökümü öncesinde kalıbın görünümü ve kalıba yerleştirilen donatılar gösterilmiştir. Şekil 2 b'de uygulanacak olan elektrik akımından temel donatılarının etkilenmemesi amacı ile yapılan bitüm uygulaması görülmektedir. Konsol bölümde ki boyuna donatılarının temele saplanan filiz boyları hem epoksi reçinesi ile yalıtılmış hem de temel üst yüzeyi bitümlenerek $\mathrm{NaCl}$ iyonlarının temele nüfuz etmesi önlenmeye çalışılmıştır (Şekil 2c). 
Boğa A.R., Koçer M., Öztürk M.: Btnrme.Elmnlrda.Dntı.Krzyn.Frklı.Hzındrımış.Krzyn.Dny.Yntmlri.ile Arşt.
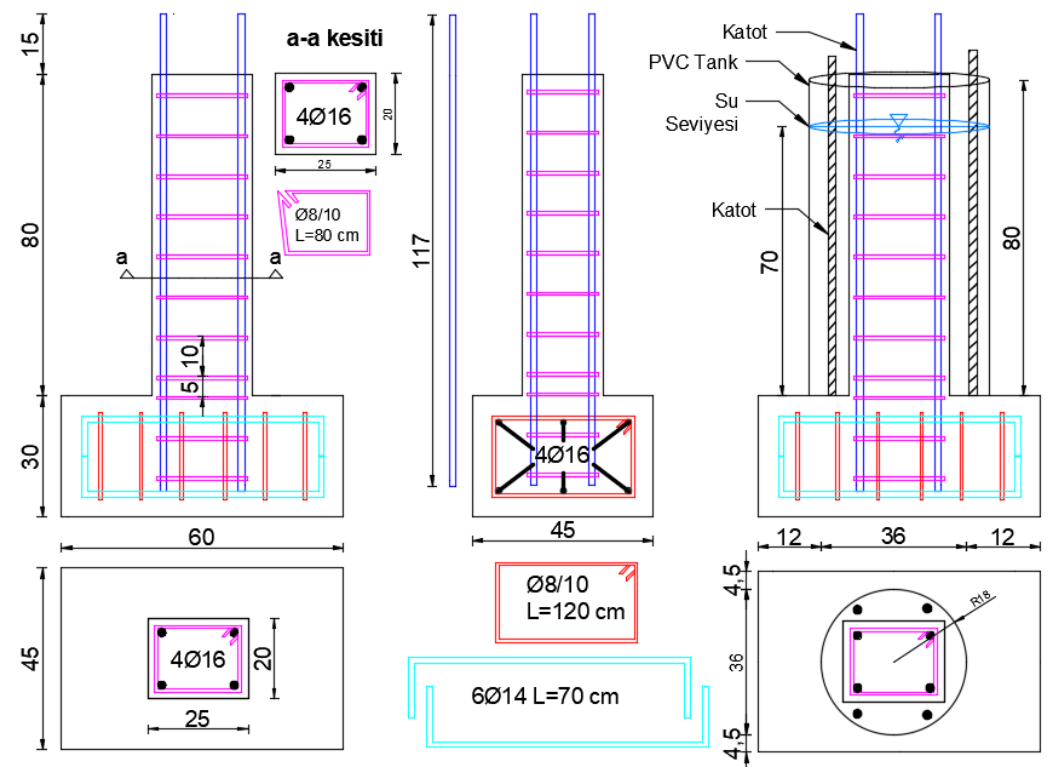

Şekil 1:

Numunelerin Detayları (cm)
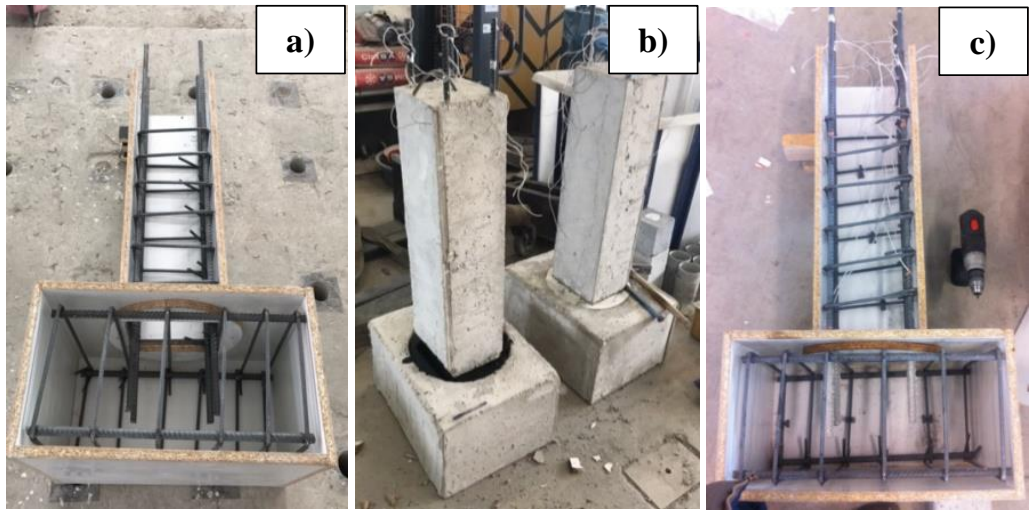

Şekil 2:

a) Kalıbın görünümü, b) Numunelerin bitümle yalıtılması, $\boldsymbol{c})$ Epoksi reçinesi ile yalıtım

Üretilen betonarme numuneler 48 saat boyunca kalıplarında bekletilmiş ve sonrasında kalıplarından çıkartılmıştır. Daha sonra betonarme elemanlara 7 gün boyunca su kürü uygulanmış ve hızlandırılmış korozyon deneylerinden önce betonarme elemanlar laboratuvar ortamında 28 gün tamamlanıncaya kadar bekletilmiştir.

\subsection{Yapılan Deneyler}

\subsubsection{Ultrases Geçiş Hızı, Basınç ve Yarmada-çekme Dayanımı Deneyleri}

Ultrases geçiş hızı ve basınç dayanımı deneyleri 150x150x150 mm boyutlarındaki 28 ve 180 günlük küre uğratılan küp numuneler üzerinde yapılmıştır. Basınç dayanımı deneyleri TS EN 12390-3 (2019)'a göre gerçekleştirilmiştir. Yarmada-çekme dayanımı deneyleri ise 28 ve 180 günlük kür sürelerinin sonunda Ø100x200 mm boyutlarındaki silindir numuneler üzerinde TS EN 12390-6 (2010)'ya göre yapılmıştır. 


\subsubsection{Betonarme Numunelerinde Hızlandırılmış Korozyon Deneyi}

Hızlandırılmış korozyon deneylerinde voltaj sabit çalışılabileceği gibi, akım sabit de çalışılabilir. Bu her iki yöntemde denenmiştir. Voltaj sabit çalışılması durumunda, devreden geçen akımın, bir veri toplama cihazı ile kaydedilmesi gerekmektedir. Böylece deneyin herhangi bir anında veri toplama cihazından elde edilen ortalama akım değeri ile geçen deney süresi aşağıda verilen Faraday denkleminde (Denklem 1) yerine konularak korozyon nedeni ile donatıda oluşan ağırlık kayıpları teorik olarak belirlenmektedir (Ma ve ark., 2012).

$$
A \breve{g} l r l l k \operatorname{kaybl}(g r)=\frac{t(s) \times I(A) \times 55,847\left(\frac{g}{\mathrm{~mol}}\right)}{2 \times 96487(\operatorname{coulomb})}
$$

Denklemdeki t zaman ve birimi saniye, I akım ve birimi amper, 55,847 $\mathrm{g} / \mathrm{mol}$ demirin atomik ağırlığı, (2) demirin değerliği $\left(\mathrm{Fe}^{+2}\right)$, (96487) faraday sabitidir.

Bulunan teorik ağırlık kaybı istenilen seviye de ise deney sonlandırılmaktadır. Akım sabit çalışılır ise, akım sabit olduğu için, istenilen teorik ağırlık kaybına ulaşmak için gerekli deney süresi deneye başlamadan önce Faraday denklemi ile belirlenebilmektedir.

Üretilen deney numuneleri özdeş olduğu için, isimlendirme verilen akım türüne göre yapılmıştır. İlk numune sabit voltaj altında, ikinci numune sabit akım altında hızlandırılmış korozyona maruz bırakılacakları için, ilk numune SV (sabit voltaj), ikinci numune SA (sabit akım) olarak isimlendirilmiştir. SV ve SA isimli numunelerde donatılar ve etriyeler birbiri ile bağlantılı oldukları için, donatılara verilen akımlar hem boyuna donatılardan hem de enine donatıların üzerinde dolaşmaktadır. Bu nedenden dolayı korozyon hem enine donatılarda hem de boyuna donatılarda oluşmaktadır.

Deney numunelerini korozyona uğratmak için elektrokimyasal metot (dış akım) kullanılmıştır. Bunun için numunelerin konsol kısmını kapsayan Ø36 cm çapındaki bir PVC boru ile Şekil 3a-b'de gösterilen bir su tankı oluşturulmuş ve özel su sızdırmaz ürünler yardımıyla temel üzerine sabitlenmiştir. Bu tankın içi $70 \mathrm{~cm}$ yüksekliğine kadar \%5'lik $\mathrm{NaCl}$ çözeltisi ile doldurularak deney düzeneği oluşturulmuştur (Şekil 3c). Konsol bölümün 70cm'lik kısmı NaCl çözeltisi içerisinde yer aldığından dolayı betonarme elemanın bu kısmında yer alan boyuna ve enine donatılar korozyona uğramıştır. Betonarme elemanın bu bölgesinde 4 adet $\varnothing 16^{\prime}$ 'l1k boyuna donatının $70 \mathrm{~cm}$ 'lik kısmı ve 7 adet etriye bulunmaktadır.

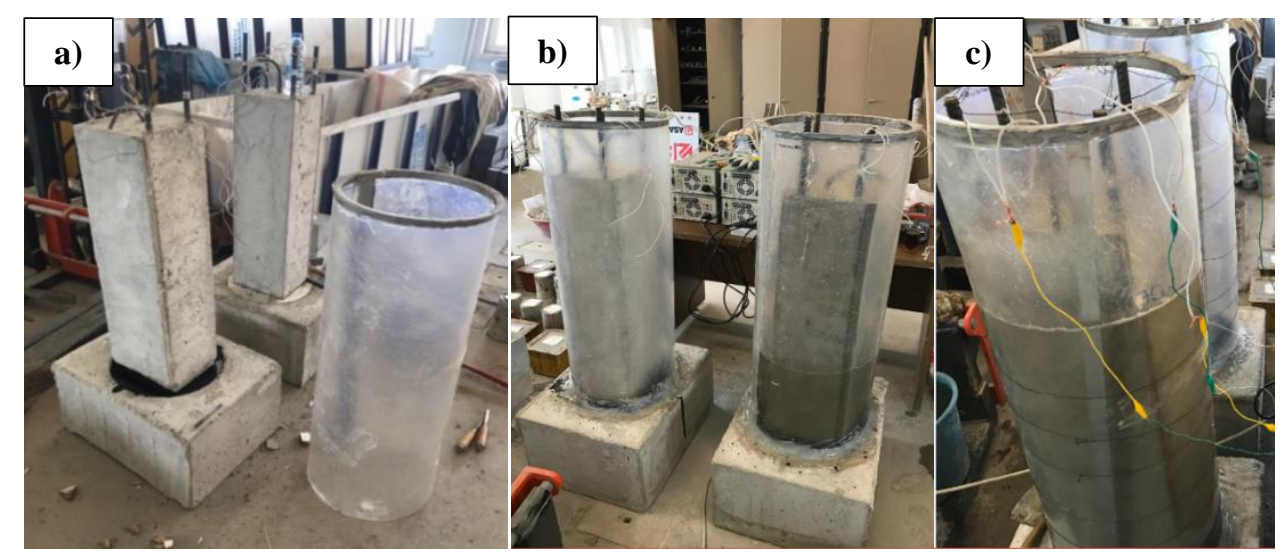

Şekil 3:

a) Tankın hazırlanması, b) Temel üstüne sabitlenmesi, $\boldsymbol{c}$ ) NaCl çözeltisi ile doldurulması

$\mathrm{Bu}$ bölgede bulunan donatıların ilk ağırlıkları donatıların birim hacim ağırlıkları ile çarpılarak bulunmuştur. Daha sonra SV isimli betonarme numunenin bu bölgesindeki donatılarda 
Boğa A.R., Koçer M., Öztürk M.: Btnrme.ElmnIrda.Dntı.Krzyn.Frklı.Hzlndrımış.Krzyn.Dny.Yntmlri.ile Arşt.

yaklaşık olarak \%5' lik ağırlık kayıpları oluşuncaya kadar korozyon deneylerine devam edilmiştir. SA isimli betonarme numunede ise ağırlık kayıpları yaklaşık olarak \% 10 oluncaya kadar korozyon deneylerine devam edilmiştir. Böylece yapılan çalışmada korozyon seviyesi SV isimli betonarme eleman için yaklaşık olarak $\% 5$, SA isimli betonarme eleman için yaklaşık olarak \%10 olarak belirlenmiştir.

\subsubsection{Sabit Voltaj Altında Hızlandırılmış Korozyon Deneyi}

Sabit voltaj altında hızlandırılmış korozyon deneyine tabi tutulan SV isimli numunenin korozyon deney düzeneği Şekil 4a'da gösterilmiştir. Burada, 4Ø16'lık konsol bölümün boyuna donatıları ve etriyeler anot görevini üstlenmektedir. Haznenin içine yerleştirilen 4 adet paslanmaz çelik levhalar ise katot görevini ve tankın içerisindeki $\mathrm{NaCl}$ çözeltisi de elektrolit görevini üstlenmektedir. Korozyon deney düzeneğinin kurulumu Şekil $4 b$ 'de gösterilmiştir. Bu deney yönteminde kullanılan deney düzeneği doğru akım kapasiteli bir güç kaynağ 1 , verilerin toplanmasında kullanılan bir veri toplama cihazı, içerisinde \%5 konsantrasyonlu $\mathrm{NaCl}$ çözeltisi ve dört adet paslanmaz çelik plaka bulunan bir plastik hazne ve betonarme numuneden oluşmaktadır.

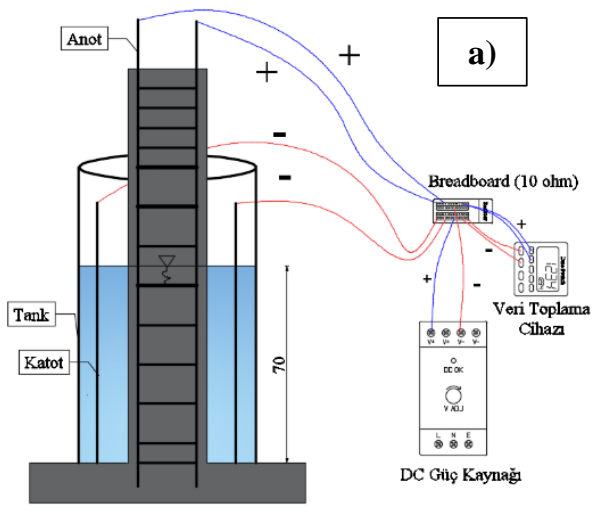

Şekil 4:

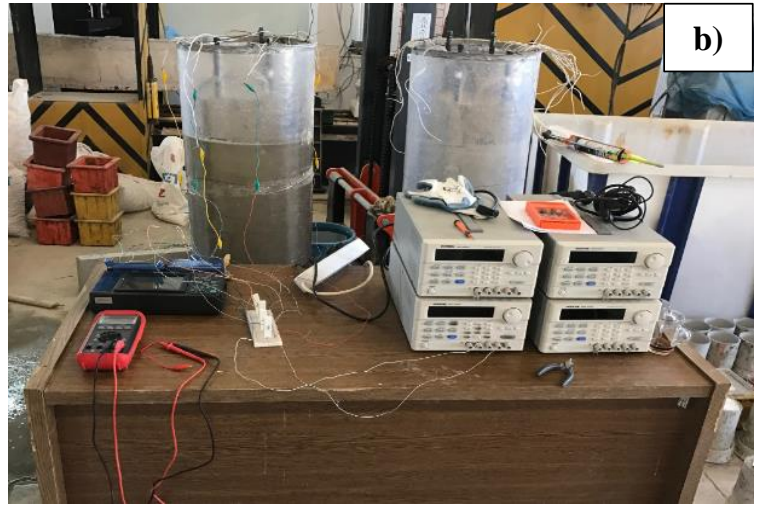

a) Korozyon deney düzeneği, b) Deneysel elektroliz devrenin kurulumu

SV isimli numunenin yaklaşık olarak \% $\%$ 'lik ağırlık kaybına kadar korozyona uğratılabilmesi için deney düzeneğinden geçen toplam ortalama akımın ve deney süresinin belirlenmesi gerekmektedir. Bu amaçla devreden geçen akımlar bir veri toplama cihazı yardımıyla her $5 \mathrm{dk}$ bir kaydedilmiştir. Böylece betonarme elemanın çektiği toplam ortalama korozyon akımı elde edilmiştir. Faraday denklemi (Denklem 1) kullanılarak donatılarda ve etriyelerde oluşan teorik ağırlık kayıpları hesaplanmıştır.

\subsubsection{Sabit Akım Altında Hızlandırılmış Korozyon Deneyi}

Sabit akım altında hızlandırılmış korozyon deneyine tabi tutulan SA isimli numunenin korozyon deney düzeneği Şekil 5'te gösterilmiştir. SA isimli numuneye sabit 1 amperlik akım uygulanmıştır. Akım sabit olduğundan yaklaşık olarak \%10'luk teorik ağırlık kaybına ulaşılana kadar deneylere devam edilmiştir. \%10'luk teorik ağırlık kaybı, betonarme elemanın $\mathrm{NaCl}$ çözeltisi içinde yer alan $70 \mathrm{~cm}$ 'lik kısmındaki boyuna ve enine donatı ağırlıklarının \%10'u alınarak belirlenmiştir. Faraday denkleminde (Denklem 1) ağırlık kaybı ve akım değerleri yerine koyularak, deney düzeneği başlatılmadan önce korozyona uğratma süresi belirlenmiş̧tir. Bu süre sonunda SA isimli numunenin hızlandırılmış korozyon deneyine son verilmiştir. 


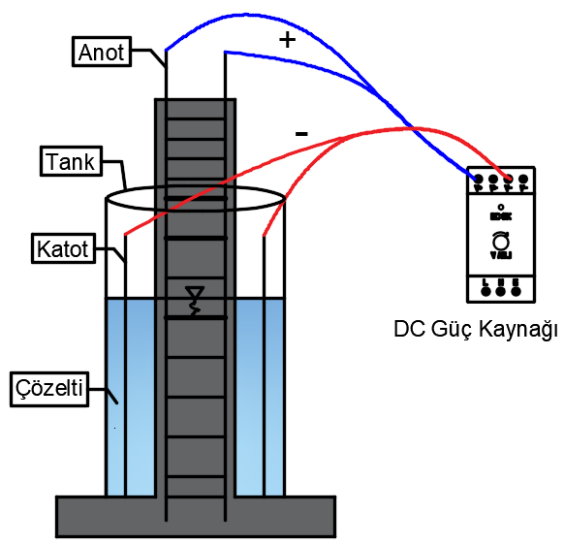

Şekil 5:

SA isimli numunenin korozyon deney düzeneği

\subsubsection{Ağırlık Kaybı Deneyi}

Betonarme numunelerin $70 \mathrm{~cm}$ 'lik kısmı $\mathrm{NaCl}$ çözeltisi içerisinde yer aldığından dolayı betonarme numunelerin bu kısmında yer alan boyuna ve enine donatılar korozyona uğramıştır. Betonarme numunelerin $70 \mathrm{~cm}$ 'lik kısmındaki 4 adet $\varnothing 16^{\prime}$ 'lı boyuna donatının ve 7 adet etriyenin ilk ağırlıkları donatıların birim hacim ağırlıkları ile çarpılarak bulunmuştur. Daha sonra SV ve SA adlı betonarme numuneler yaklaşık olarak sırasıyla $\% 5$ ve 10 teorik ağırlık kayıplarına kadar korozyona uğratılmışlardır. Korozyon işlemlerinin sonrasında bu bölgedeki boyuna ve enine donatılar betonarme numunelerin içerisinden çıkartılmışlardır. Çıkartılan donatılar pas ve beton artıklarından HCL çözeltisi ile temizlendikten sonra ağırlık ölçüm işlemi yapılmıştır. Bu işlemlerin sonrasında SA ve SV isimli betonarme numunelerin donatılarında oluşan gerçek ağırlık kayıpları hesaplanmıştır.

\subsection{4. Çekme Deneyi}

Korozyon deneyleri sonrasında betonarme numunelerin içerisinden çıkartılan ve temizlenen Ø8'lik ve Ø16'lık donatılara üniversal çekme deney cihazı ile çekme deneyleri TS EN ISO 68921 (2020) ve TS EN ISO 15630-1 (2019) standartlarına göre yapılmıştır. Ayrıca kontrol amacıyla hiç korozyona uğratılmayan Ø8 ve 16'lık donatılara da çekme deneyleri yapılmıştır. Çekme deneyleri sonucunda donatıların akma ve çekme dayanımları ile şekil değiştirme yüzdeleri belirlenmiştir. Kontrol serilerinin TS 708 (2016)'de verilen sınır değerleri sağladıkları görülmüştür.

\section{DENEY SONUÇLARI VE DEĞERLENDİRILMESI}

\subsection{Ultrases Geçiş Hızı ve Birim Ağırık Deneyi Sonuçları}

Ultrases geçiş hızı ve birim ağırlık deneyi sonuçları Tablo 3'te gösterilmiştir. Tablo 3 incelendiğinde kür sürelerinin artışı ile birlikte ultrases geçiş hızı değerlerinin ve birim ağırlık sonuçlarının arttığı sonucuna varılmıştır. Kür sürelerinin artması ile birlikte hidratasyon reaksiyonları devam etmiş ve ultrases geçiş hızı sonuçlarından görüldüğü üzere daha boşluksuz betonlar elde edilmiştir. 
Boğa A.R., Koçer M., Öztürk M.: Btnrme.Elmnırda.Dntı.Krzyn.Frklı.HzIndrımış.Krzyn.Dny.Yntmlri.ile Arşt.

Tablo 3. Ultrases geçiş hızı ve birim ağırılı deneyi sonuçları

\begin{tabular}{|c|c|c|}
\hline Kür süresi & Ultrases Geçiş Hızı, km/sn & Birim A Ăırlık, $\mathrm{kg} / \mathrm{m}^{3}$ \\
\hline 28 & 4,13 & 2309 \\
\hline 180 & 4,49 & 2358 \\
\hline
\end{tabular}

\subsection{Basınç ve Yarmada-Çekme Dayanımı Deneyi Sonuçları}

Basınç ve yarmada-çekme dayanımı ile ilgili sonuçlar Şekil 6'da verilmiştir. Şekil 6'dan da görüldüğü üzere kür sürelerinin artışı ile birlikte basınç ve yarmada-çekme dayanımı değerlerinde artışlar olmuştur. Basınç dayanımın değerleri daha yüksek oranlarda artarken yarmada-çekme dayanımı değerleri daha az oranlarda artmıştır. Kür süresi 28 gün olan numunelerden elde edilen basınç dayanımı değerleri yaklaşı $15 \mathrm{MPa}$ seviyesindeyken 180 gün boyunca kür uygulanan numunelerin basınç dayanımı değerleri 19 MPa seviyelerine ulaşmıştır. Basınç dayanımlarındaki bu artışların nedeni, ultrases geçiş hızı değerlerinden de görüldüğü üzere kür sürelerinin artışı ile birlikte hidratasyonun devam etmesi ve betonların daha boşluksuz hale gelmelerinden kaynaklanmaktadır.

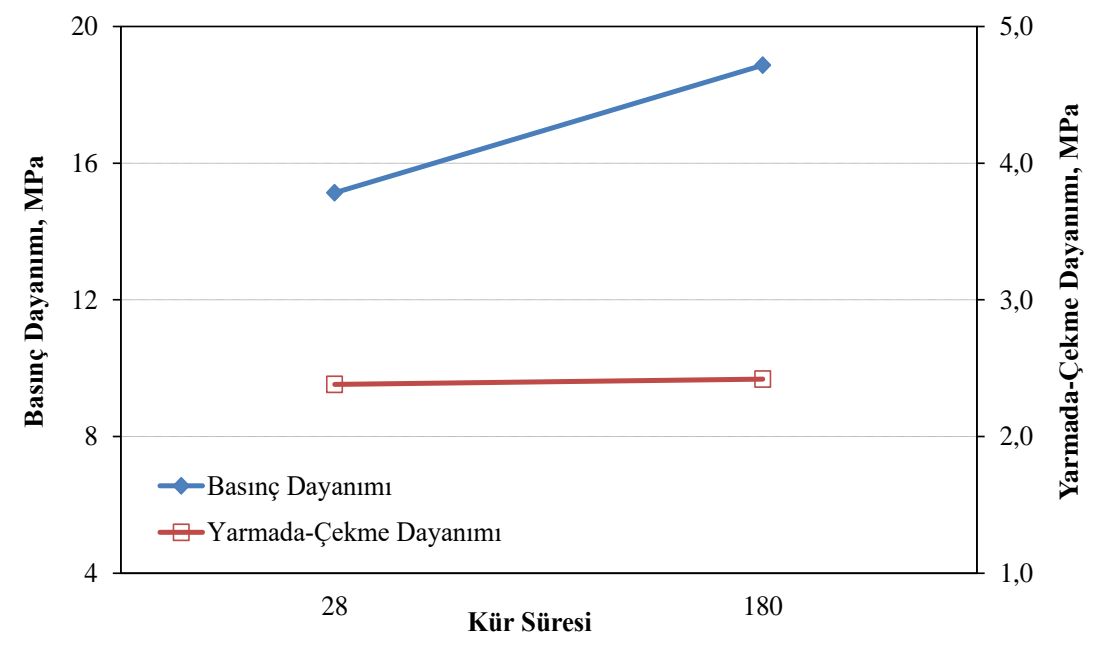

Şekil 6:

Basınç ve yarmada-çekme dayanımı deney sonuçlarının kür süresine göre değişimi

\subsection{Sabit voltaj altında hızlandırılmış korozyon deneyi sonuçları}

Sabit voltaj (SV) uygulanan betonarme numunenin her bir donatısından elde edilen zamana bağlı korozyon akımlarının değişimi Şekil 7'de gösterilmiştir. Etriyelerde boyuna donatılara bağlı olduğundan dolayı elde edilen korozyon akımları, hem boyuna donatıların hem de etriyelerin çektiği korozyon akımlarını ifade etmektedir.

Donatıların çektiği ortalama korozyon akımları ve çekilen akımlardan elde edilen teorik ağırlık kayıpları Şekil 8'de verilmiştir. Her bir donatının üzerine DC güç kaynağı ile 12 V'luk sabit voltaj uygulanmıştır. Tüm donatılara aynı voltajın uygulanabilmesi için sistem paralel olarak bağlanmıştır. Çekilen toplam akım paralel olarak bağlanan her bir donatıdan elde edilen akımların toplanması ile bulunmuştur. Sabit voltaj altındaki betonarme elemanın çektiği toplam ortalama akım 1,629 A olarak elde edilmiştir. Ayrıca her bir donatının çektiği ortalama korozyon akımları ve korozyona uğratılma süreleri Faraday denkleminde yerine konularak teorik ağılık kayıpları da hesaplanmıştır. Betonarme elemandan elde edilen toplam teorik ağırlık kaybı 363,70 gr olarak elde edilmiştir. 


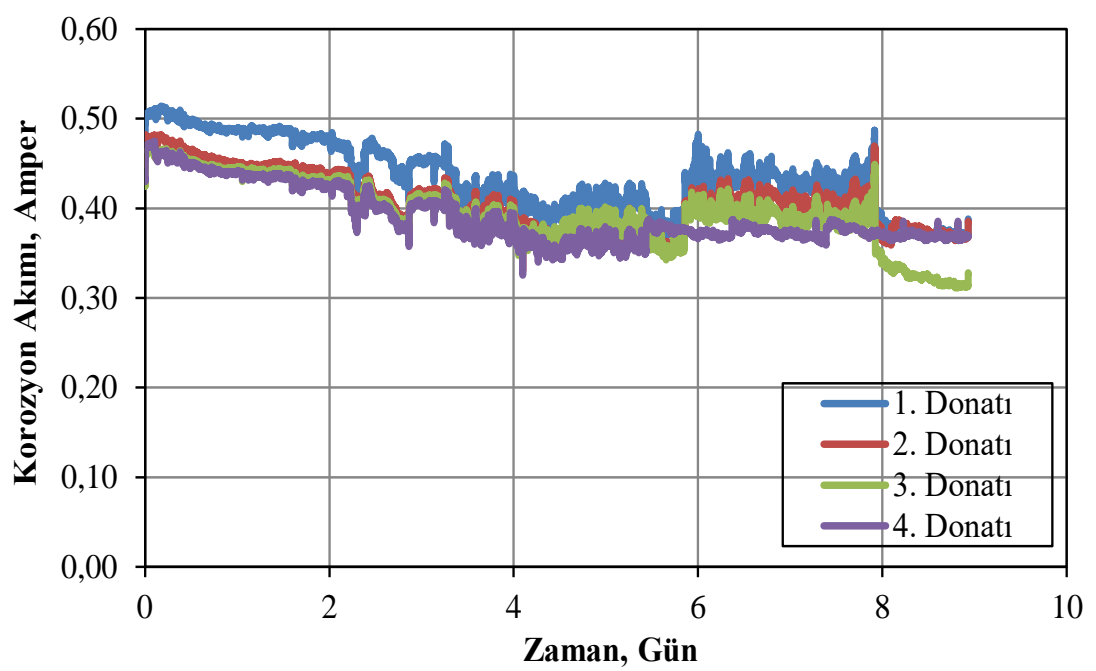

Şekil 7:

Korozyon akımlarının zamana göre değişimi

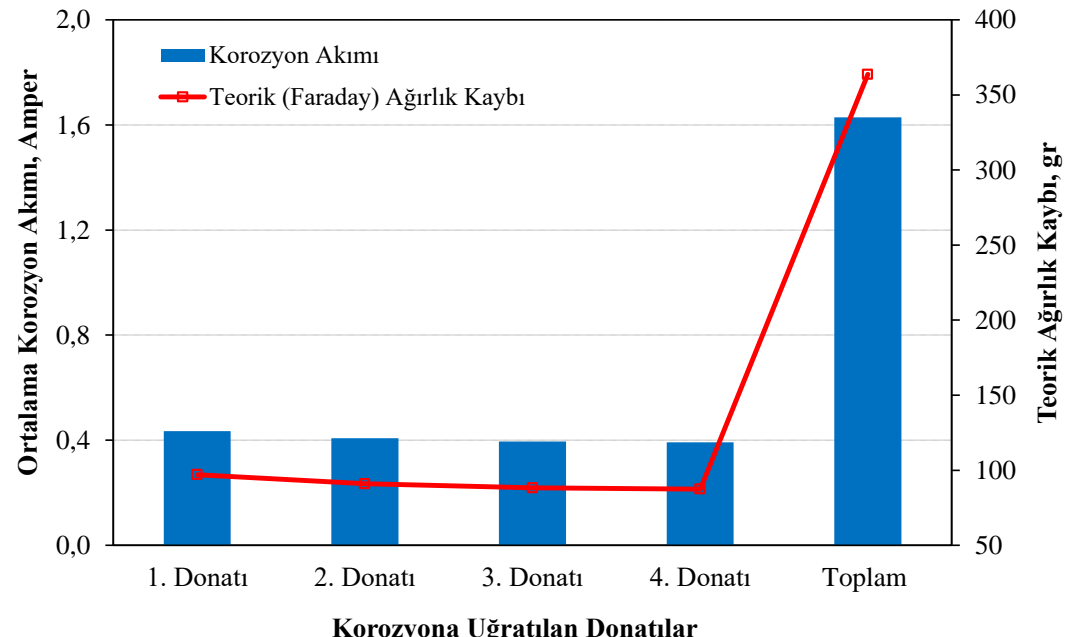

Şekil 8:

Donatılarda oluşan ortalama korozyon akımları ve teorik ağırlık kayıpları

SV isimli numunenin deneyi sona erdikten sonra haznesi çıkartılarak, numune üzerinde gözlemsel bir inceleme yapılmıştır. Numunedeki pas oluşumu ve pas tabakası kaldırıldıktan sonraki numunenin korozyon hasarlı hali Şekil 9'da görülmektedir. Şekil 10'da pas pay1 tabakaları sıyrılarak korozyonun donatılar üzerindeki dağılışı incelenmiş ve görüldügü üzere homojen bir pas tabakasının oluştuğu gözlemlenmiştir. 


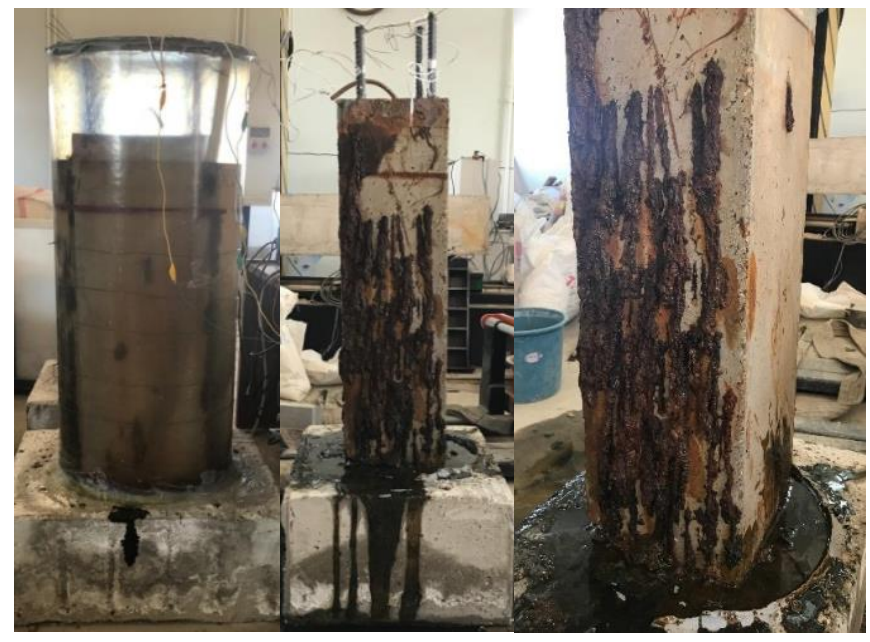

Şekil 9:

Deney sonrası SV isimli numunenin görünümü

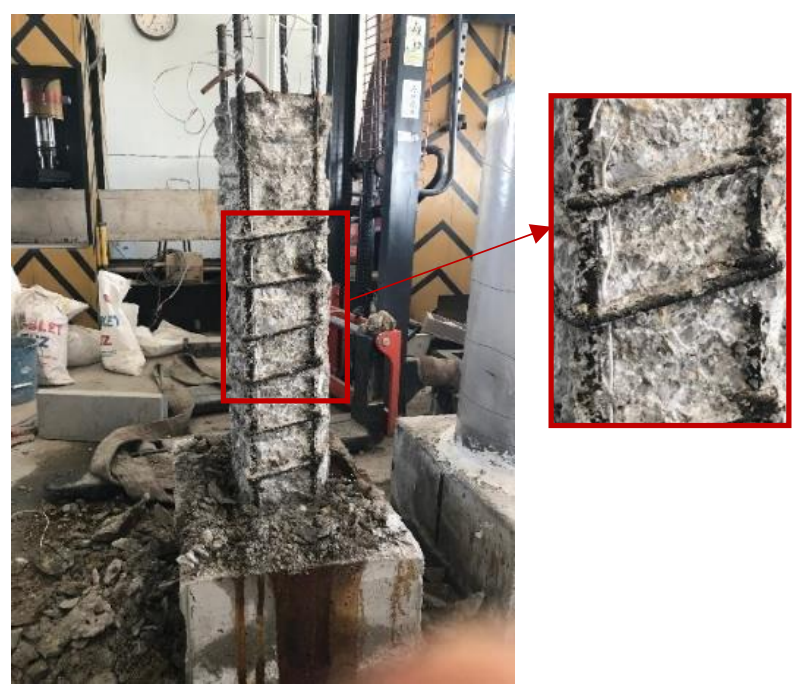

Şekil 10:

SV isimli numunede beton örtülerinin slyrllması ve korozyon dă̆llımı

\subsection{Sabit akım altında hızlandırılmış korozyon deneyi sonuçları}

Betonarme elemanın $70 \mathrm{~cm}$ 'lik kısmındaki donatıların ilk ağırlıkları donatıların birim hacim ağırlıkları ile çarpılarak bulunmuş ve bulunan bu ağırlığın yaklaşık olarak \%10'u oranına kadar ağırlık kaybı oluşuncaya kadar betonarme eleman korozyona uğratılmıştır. Korozyon deneyinde akım 1A olacak şekilde sabit tutulmuş ve korozyon deneyine yaklaşık olarak 26,54 gün (2293056 saniye) boyunca devam edilmiştir. SA isimli betonarme numunesindeki pas oluşumu ve korozyon hasarlı hali Şekil 11'de görülmektedir. Sabit akım altında hızlandırılmış korozyon deneyinden elde edilen teorik ağırlık kaybı değeri 663,61 gr olarak elde edilmiştir. 


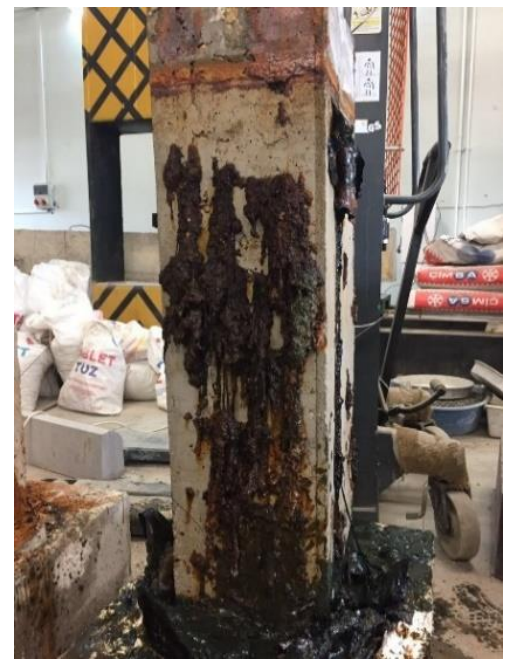

Şekil 11:

Deney sonrası SA isimli numunenin görünümü

\subsection{Ağırlık Kaybı Deneyi Sonuçları}

SV ve SA isimli betonarme numunelerdeki boyuna ve enine donatılardan örnekler alınarak ilk olarak gözlemsel inceleme yapılmış ve daha sonra örnekler HCL asit çözeltisi ile temizlenerek beton ve pas kalıntılarından uzaklaştırılmıştır. Daha sonra donatılarda oluşan gerçek ağırlık kayıpları belirlenmiş̧tir. Gerçek ve teorik ağırlık kayıpları arasındaki farkları göstermek için Şekil 12 düzenlenmiştir.

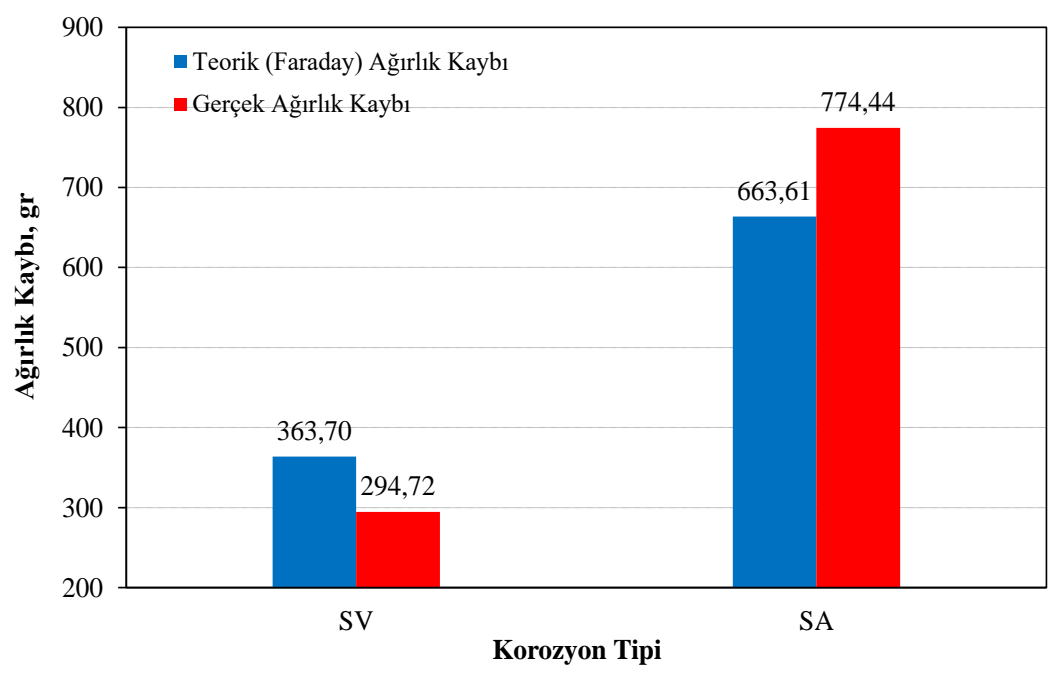

Şekil 12:

Korozyon deneyleri sonrasında betonarme elemanın boyuna ve enine donatılarında oluşan ă̆ırlık kayıpları

Şekil 12'de korozyon tipine bağlı olarak elde edilen teorik ve gerçek ağırlık kaybı değerleri verilmiştir. Elde edilen ağırlık kaybı değerleri betonarme numunelerdeki hem etriyelerde hem de boyuna donatılarda oluşan ağırlık kaybı değerlerini göstermektedir. Şekil 12 incelendiğinde sabit voltaj (SV) altında korozyona uğratılan betonarme numunelerdeki donatılardan teorik olarak 
363,70 gr ağırlık kaybı elde edilirken, HCL asit çözeltisi ile temizlendikten sonra donatılardan 294,72 gr'lık gerçek ağırlık kaybı değeri elde edilmiştir. Sonuç olarak, korozyon tipi SV olan serilerden elde edilen gerçek ağırlık kaybı sonuçları teorik ağırlık kaybı sonuçlarına göre daha az olarak elde edilmiştir. Sabit akım (SA) altında korozyona uğratılan serilerde ise teorik ağırlık kaybı değeri 663,61 gr olarak elde edilirken, gerçek ağırlık kaybı değeri 774,44 gr olarak elde edilmiştir. SV serisinden farklı olarak SA serisinde, gerçek ağırlık kaybı değeri teorik ağırlık kaybı değerlerine göre daha fazla elde edilmiştir. Her iki korozyon tipinde de teorik ağırlık kayıpları ile gerçek ağırlık kayıpları arasında yaklaşık olarak 70 ile 100 gr aralığında farklar elde edilmiştir.

Şekil 13’te korozyon tipine bağlı olarak elde edilen teorik ve gerçek ağırlık kaybı yüzdeleri verilmiştir. Ağırlık kaybı yüzdeleri, betonarme elemanın $70 \mathrm{~cm}$ 'lik kısmındaki donatı ağırlıkları elde edilen ağırlık kaybı değerlerine oranlanarak elde edilmiştir. Betonarme elemanın sabit voltaj (SV) altında yaklaşık olarak \% 5 oranında ağırlık kaybı oluşuncaya kadar korozyona uğratılmıştır. Betonarme elemandan teorik olarak \% 5,49 oranında ağırlık kaybı değeri elde edilirken gerçek ağırlık kaybı \% 4,44 oranında elde edilmiştir. SV isimli seride teorik ve gerçek ağırlık kaybı değerleri arasında yaklaşık olarak \% 1'lik fark oluşmuş̧ur. Ancak yine de birbirine oldukça yakın değerler elde edilmiştir. SA isimli sabit akım altında korozyona uğratılan betonarme elemanın donatılarından yaklaşık olarak \% 10 oranında ağırlık kaybı olacak şekilde korozyona uğratılmıştır. Korozyon deneyi sonrasında donatılardan elde edilen ağırlık kaybı yüzdeleri teorik ve gerçek olacak şekilde sirasıyla \% 10,01 ve 11,68 değerlerindedir. SA isimli seride teorik ve gerçek ağırlık kayıpları arasında yaklaşık olarak \% 1,7 oranında fark oluşmuştur. Sonuç olarak teorik ve gerçek ağırlık kaybı değerleri, SV serilerinde olduğu gibi SA serilerinde de birbirine oldukça yakın olarak elde edilmiştir.

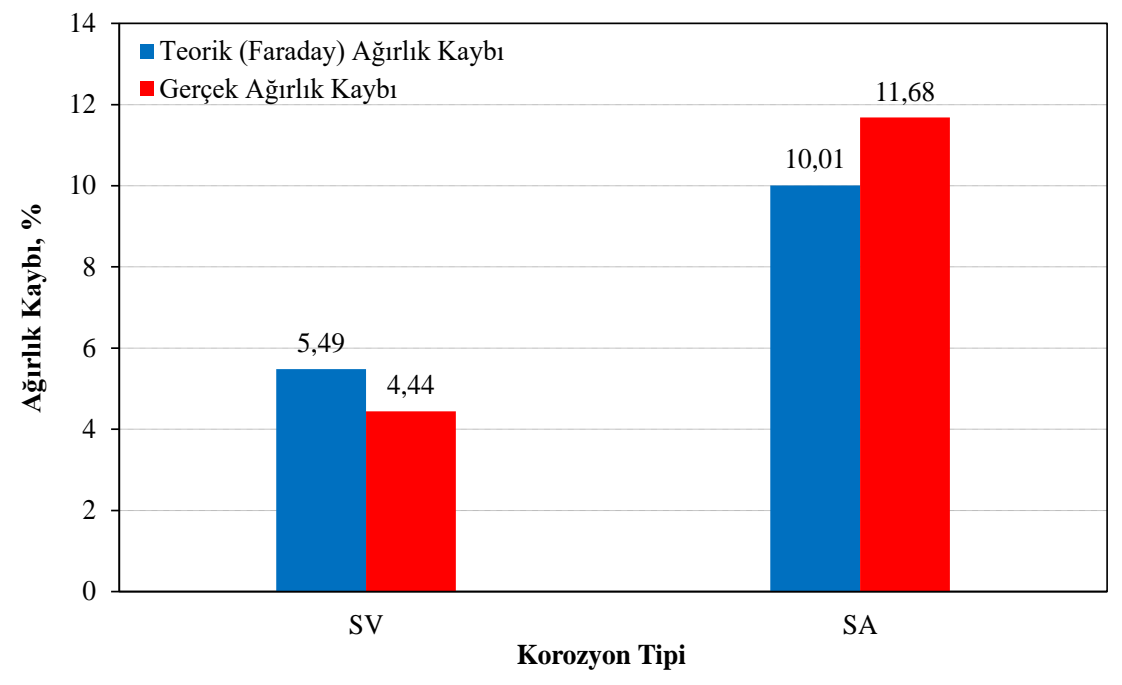

Şekil 13:

Korozyon deneyleri sonrasında betonarme elemanın boyuna ve enine donatılarında oluşan ăgırlık kaybı yüzdeleri

\section{6. Çekme Deneyi Sonuçları}

Donatıların çekme deneyleri sonucunda elde edilen gerilme şekil değiştirme eğrileri Şekil 14 ve 15 'de verilmiştir. Şekil 14'te çapı $16 \mathrm{~mm}$ olan boyuna donatılardan, Şekil 15 'te çapı $8 \mathrm{~mm}$ olan etriye donatılarından elde edilen gerilme şekil değiştirme eğrileri verilmiştir. Şekil 14 incelendiğinde, hiç korozyona uğratılmayan kontrol serilerine göre sabit voltaj (SV) ve sabit akım (SA) altında korozyona uğratılan serilerin akma ve çekme dayanımlarında azalmaların olduğu 
görülmüş̧ür. SA serileri SV serilerine göre daha fazla ağırlık kaybı oluşuncaya kadar korozyona uğratıldıkları için SA serilerinden daha düşük akma ve çekme dayanımı değerleri elde edilmiştir.

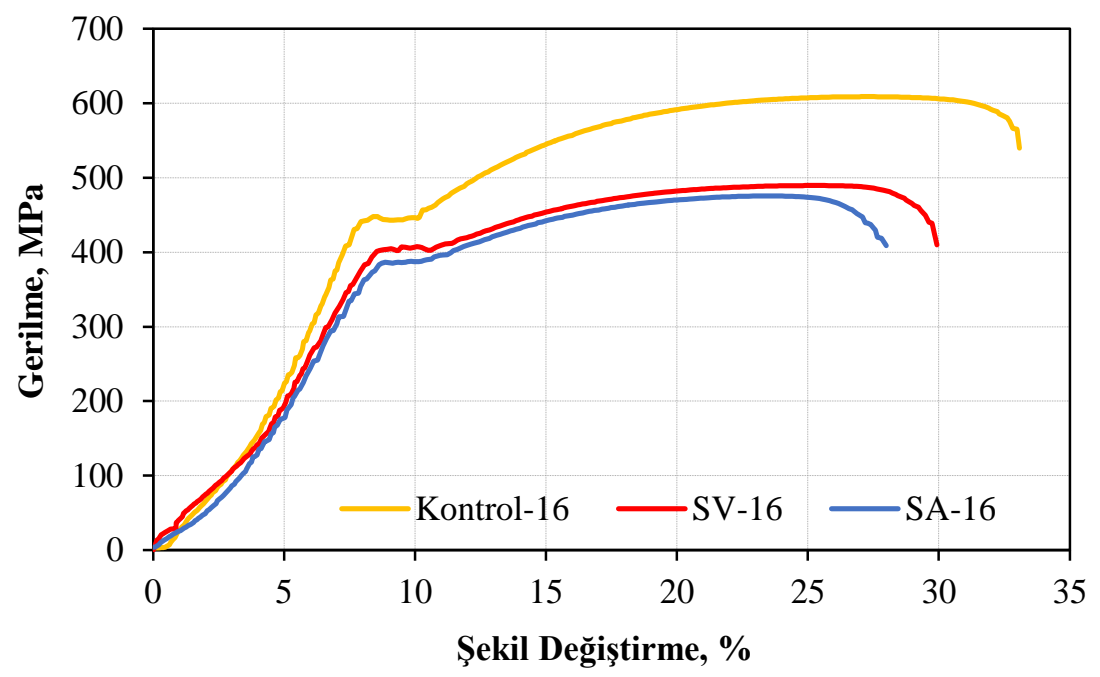

Şekil 14:

Korozyon tipine bağglı olarak boyuna donatıların gerilme şekil değisştirme ĕgrileri

Șekil 15 'ten de görüldüğü üzere, $8 \mathrm{~mm}$ 'lik donatılardan elde edilen akma ve çekme dayanımları 16mm'lik donatılarda olduğu gibi korozyona uğratılan serilerden daha düşük olarak elde edilmiştir. Ayrıca korozyona uğrama derecelerinin artması ile birlikte şekil değiştirmelerde azalmaların olduğu sonucuna da varılmıştır. SA-8 serilerinden elde edilen gerilme şekil değiştirme eğrisi incelendiğinde akma bölgesinin belirgin bir şekilde oluşmadığı görülmüştür.

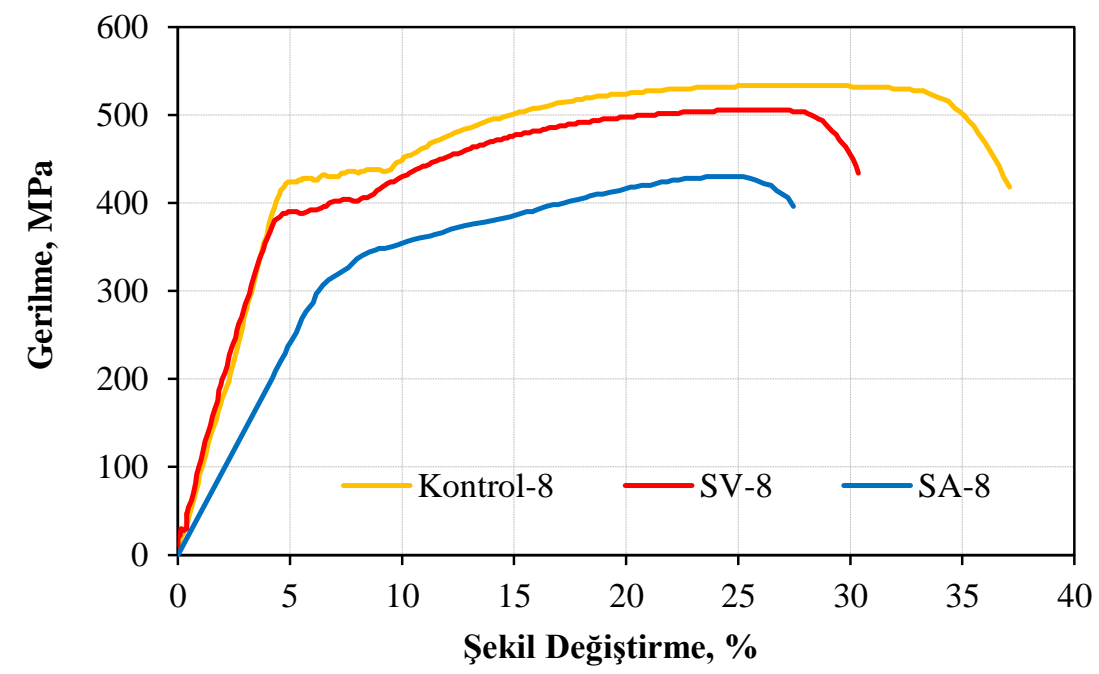

Şekil 15:

Korozyon tipine bağlı olarak enine donatıların gerilme şekil değiştirme eğrileri

Korozyon serilerine göre akma dayanımlarımdaki değişimler Şekil 16'da verilmiştir. Şekilde Kontrol-8 ve Kontrol-16 olarak adlandırılan seriler hiç korozyona uğratılmayan 8 ve 16 mm'lik donatıları tanımlamaktadır. SV-8 ve SV-16 olarak adlandırılan seriler sabit voltaj altında yaklaşık olarak \% 5 ağırlık kaybına kadar korozyona uğratılan 8 ve 16 mm'lik donatıları göstermektedir. 
Boğa A.R., Koçer M., Öztürk M.: Btnrme.ElmnIrda.Dntı.Krzyn.Frklı.Hzlndrımış.Krzyn.Dny.Yntmlri.ile Arşt.

SA-8 ve SA-16 olarak adlandırılan seriler ise sabit akım altında yaklaşık olarak \% 10 ağırlık kaybına kadar korozyona uğratılan 8 ve 16 mm'lik donatıları tanımlamaktadır.

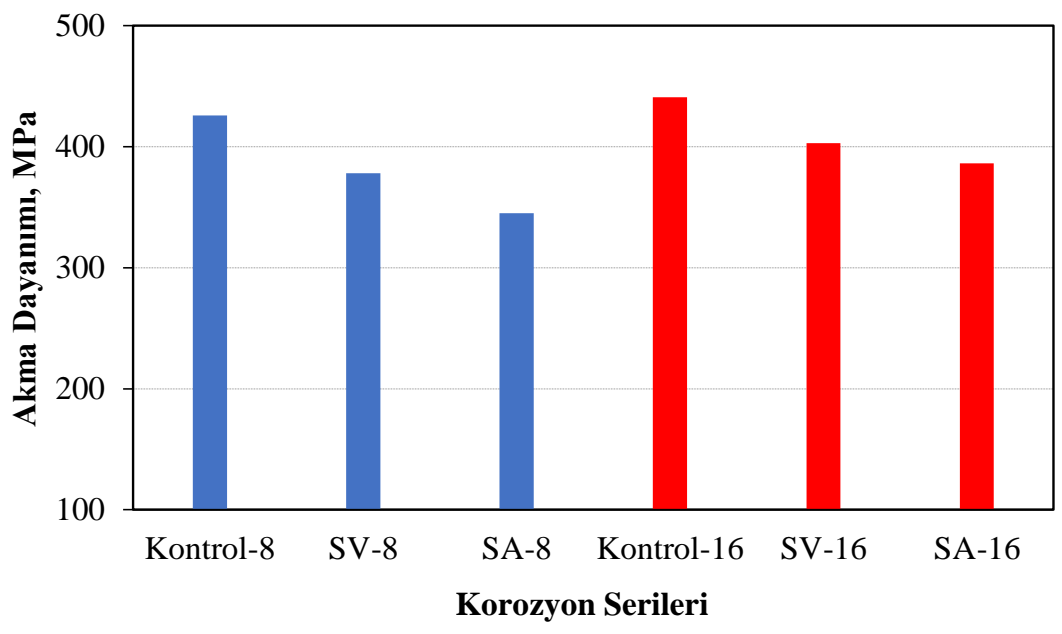

Şekil 16:

Korozyon serilerine göre akma dayanımlarının değişimi

Şekil 16 incelendiğinde her iki donatı çapında da korozyona uğratılma ile birlikte akma dayanımlarında azalışların olduğu görülmüştür. Kontrol-8 serilerinin akma dayanımları $426 \mathrm{MPa}$ olarak elde edilirken SV-8 ve SA-8 serilerinden sirasıyla 378 ve 345 MPa'lık akma dayanımları elde edilmiştir. Şekil 16'dan görüldügü üzere SV-8 ve SA-8 serilerinin akma dayanımları, Kontrol-8 serisinin akma dayanımına göre sırasıyla \% 11,27 ve 19,01 oranlarında azalmıştır. Kontrol-16 serisinde $441 \mathrm{MPa}$ 'lk akma dayanımı elde edilirken SV-16 ve SA-16 serilerinden sırasıyla 403 ve 386,2 MPa'lık akma dayanımları elde edilmiştir. SV-16 ve SA-16 serilerinden elde edilen akma dayanımlarındaki azalış oranları ise sırasıyla \% 8,62 ve 12,43 olarak bulunmuştur. Korozyon serilerine göre çekme dayanımlarımdaki değişimler Şekil 17'de verilmiş̧ir.

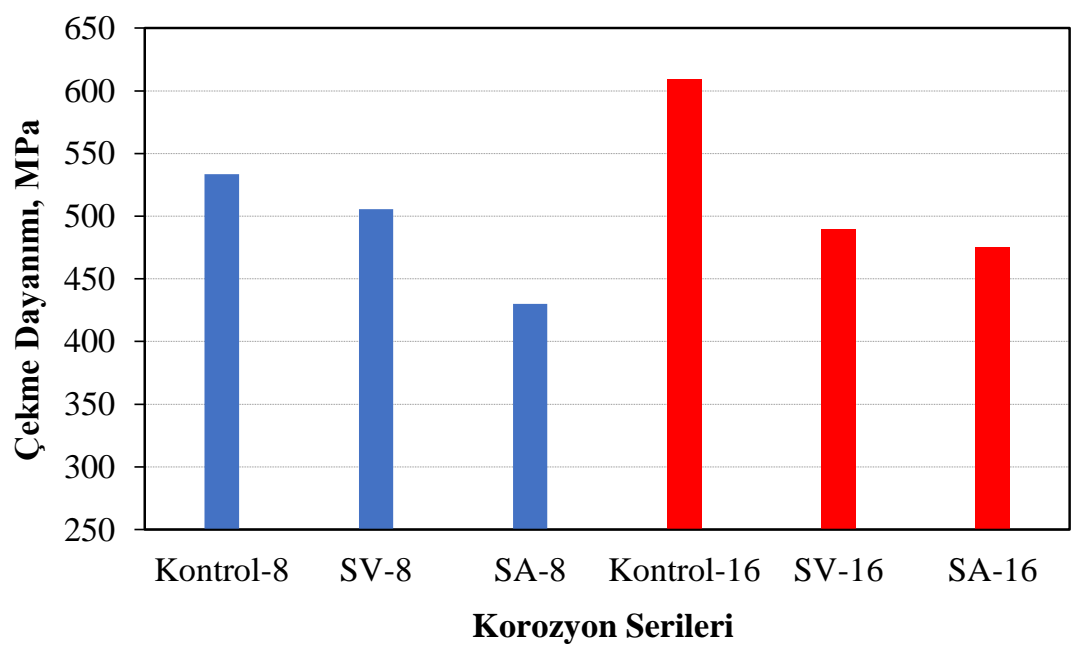

Şekil 17:

Korozyon serilerine göre çekme dayanımlarının değişimi 
Şekil 17'den görüldüğü üzere korozyona uğratılma ile birlikte çekme dayanımları her iki donatı çapında da azalmıştır. Kontrol-8 serisinden elde edilen çekme dayanımı değeri 533,4 MPa olarak elde edilirken SV-8 ve SA-8 serilerinden sirasiyla 505,6 ve 429,9 MPa olarak elde edilmiştir. Kontrol-16, SV-16 ve SA-16 serilerinden elde edilen çekme dayanımları sırasıyla 609,1, 489,7 ve 475,6 MPa olarak bulunmuştur. Korozyon serilerine göre şekil değiştirmelerin değişimi Şekil 18 'de verilmiştir.

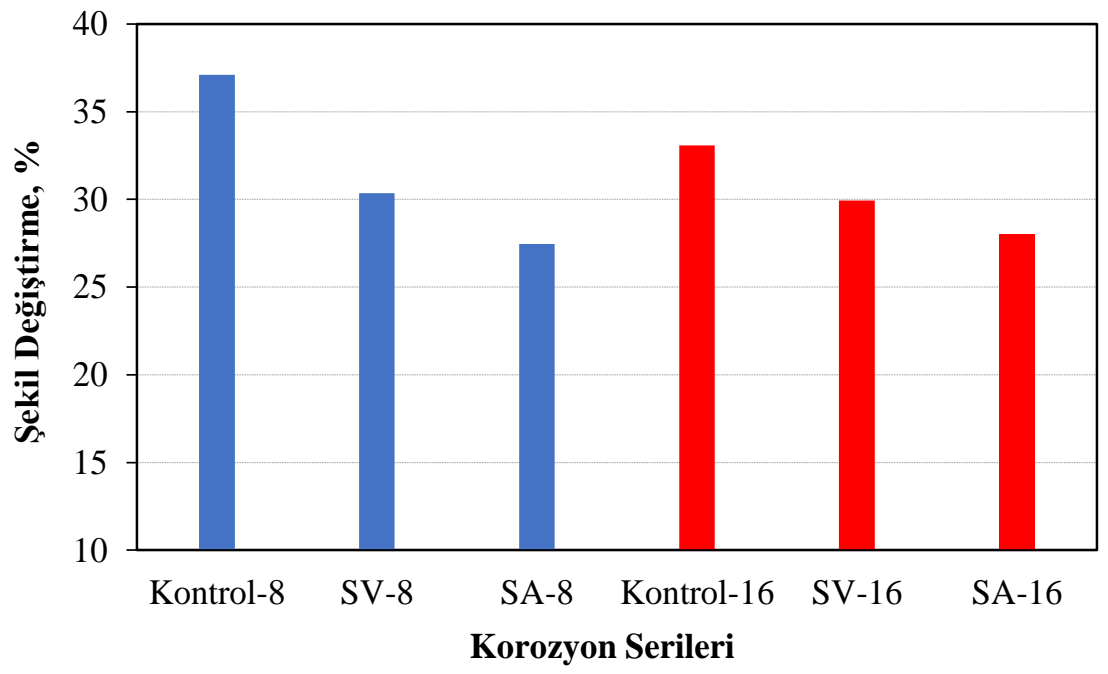

Sekil 18:

Korozyon serilerine göre şekil değiştirmelerin değişimi

Şekil 18 incelendiğinde korozyona uğrama derecelerinin artması ile birlikte şekil değiştirme yüzdelerinin azaldığı sonucuna varılmıştır. SA-8 serilerinden \% 27,47 ile en az şekil değiştirme yüzdesi değerleri elde edilmiştir. Korozyona uğrama ile birlikte donatıların süneklik değerlerinde azalmaların meydana geldiği sonucuna ulaşılmıştır. Bu istenmeyen durumları önlemek için daha geçirimsiz ve kaliteli betonlar üretilerek betonların içerisindeki donatıların korozyona uğramaları önlenmelidir.

\section{SONUÇ ve ÖNERILER}

Sabit voltaj ve sabit akım altında korozyona uğratılan betonarme elemanlar üzerinde yapılan çalışmaların sonucunda aşağıda maddeler halinde verilen sonuçlar elde edilmiştir.

- Beton numunelerinin üzerinde yapılan deneyler sonucunda kür sürelerinin artışı ile birlikte ultrases geçiş hızı değerlerinin artığı sonucuna varılmıştır.

- Kür sürelerinin artışı ile birlikte basınç ve yarmada-çekme dayanımı değerlerinde artışlar olmuştur. Kür süresi 28 ve 180 gün olan numunelerden elde edilen basınç dayanımı değerleri sırasıyla yaklaşık olarak 15 ve $19 \mathrm{MPa}$ olarak bulunmuştur.

- Sabit voltaj ve sabit akım altında korozyona uğrayan betonarme numunelerden pas payı tabakaları sıyrılarak korozyonun donatılar üzerindeki dağılışı incelenmiş ve homojen bir pas tabakasının oluştuğu gözlemlenmiştir.

- Betonarme elemanda kullanılan donatılarda sabit voltaj altında teorik olarak \% 5,49 oranında ağırlık kaybı değeri elde edilirken gerçek ağırlık kaybı \% 4,44 oranında elde edilmiştir. Sabit akım altında korozyona uğratılan serilerden ise teorik ve gerçek ağırlık kayıpları sırasıyla \% 10,01 ve 11,68 olarak elde edilmiştir. Sonuç olarak teorik ve gerçek ağırlık kaybı değerleri her iki korozyon tipinde de birbirine oldukça yakın olarak elde edilmiştir. 
- Hızlandırılmış korozyon deneyleri sabit voltaj altında gerçekleştirilirse, devredeki akım betonun yapısında meydana gelen bozulmalar yüzünden (beton yapısında meydana gelen çatlaklar, klor iyonlarının donatıya nüfus etme hızını artırarak akımın stabil yapısını bozmaktadır) zamanla değişkenlik göstermektedir ve deney süresi boyunca kaydedilmesi gerekmektedir. Veri toplama cihazı ile kaydedilen akım değerinin ortalaması ile numunede meydana gelen ağırlık kaybı veya istenilen ağırlık kaybı için deney süresi Faraday denklemi ile belirlenmektedir. Akım sabit çalışıldığında ise, istenilen teorik ağırlık kaybına ulaşmak için gerekli deney süresi deneye başlamadan Faraday denklemi ile belirlenebilmektedir ve akım sabit olduğu için akım verilerinin kaydedilmesine gerek yoktur. Bu yöntemle istenilen ağıllık kayıplarına hızlı bir şekilde ve daha düşük maliyetli bir deney düzeneği ile ulaşılabilmektedir. Korozyon dayanıklılı̆̆ına karşı beton kalitesinin, paspayının, klorür iyonları konsantrasyonunun, beton difüzyonunun etkileri hakkında bilgi sahibi olunabilmesi için güç kaynaklarının yanında veri toplama sistemlerinin de olduğu deney düzeneklerinin kurulması gerekmektedir.

- Betonarme elemanın içerisindeki donatıların korozyona uğraması ile akma ve çekme dayanımları azalmaktadır. SV-8 ve SA-8 serilerinin akma dayanımları Kontrol-8 serisinin akma dayanımına göre sırasıyla \% 11,27 ve 19,01 oranlarında azalmıştır. SV-16 ve SA16 serilerinden elde edilen akma dayanımlarındaki azalış oranları ise sırasıyla $\% 8,62$ ve 12,43 olarak bulunmuştur.

- Korozyon nedeniyle betonarme elemanın içerisindeki donatıların şekil değiştirme yüzdeleri yani süneklikleri azalmıştır.

Sonuç olarak hem sabit voltaj hem de sabit akım yöntemiyle teorik ve gerçek ağırlık kayıplarının birbirine oldukça yakın bir şekilde elde edilebileceği görülmüştür. Ayrıca korozyon nedeniyle donatıların akma ve çekme dayanımı değerlerinin azaldığı sonucuna varılmıştır. Bu sebepten dolayı betonarme bir eleman üretilirken geçirimsiz yüksek kaliteli beton kullanılması gerekmektedir. Ayrıca beton üretiminde mineral veya kimyasal katkılar kullanılarak korozyona karşı betonun dayanıklılığı arttırılmalıdır.

\section{KAYNAKLAR}

1. Bousias, S. N., Spathis, L., Triantafillou, T. ve Fardis, M. N. (2002) Seismic Retrofitting of Corrosion-Damaged RC Columns, 12th European Conference on Earthquake Engineering, 9-13 September, London.

2. Di Carlo, F., Meda, A. ve Rinaldi, Z., 2017, Numerical evaluation of the corrosion influence on the cyclic behaviour of RC columns, Engineering Structures, 153, 264-278. doi:10.1016/j.engstruct.2017.10.020

3. Doğan, M. (2009) Betonarme yapılardaki deprem hasarlarına korozyonun etkisi, Eskişehir Osmangazi Üniversitesi Mühendislik ve Mimarlık Fakültesi Dergisi, 22 (1), 147-168.

4. Göksu, C. ve İlki, A. (2016) Seismic Behavior of Reinforced Concrete Columns with Corroded Deformed Reinforcing Bars, ACI Structural Journal, 113 (5), 1053-1064. doi: $10.14359 / 51689030$

5. http://www.thbb.org/teknik-bilgiler/raporlar/elazig-depremi/, Erişim Tarihi: 01.06.2020, Konu: Elâzı̆g Depremi İnceleme Raporu.

6. Li, J. B., Gong, J. X. ve Wang, L. C. (2009) Seismic behavior of corrosion-damaged reinforced concrete columns strengthened using combined carbon fiber-reinforced polymer and steel jacket, Construction and Building Materials, 23 (7), 2653-2663. doi:10.1016/j.conbuildmat.2009.01.003 
7. Liu, X. J., Jiang, H. J. ve He, L. S. (2017) Experimental investigation on seismic performance of corroded reinforced concrete moment-resisting frames, Engineering Structures, 153, 639652. doi:10.1016/j.engstruct.2017.10.034

8. Ma, Y., Che, Y. ve Gong, J. X. (2012) Behavior of corrosion damaged circular reinforced concrete columns under cyclic loading, Construction and Building Materials, 29, 548-556. doi:10.1016/j.conbuildmat.2011.11.002

9. Meda, A., Mostosi, S., Rinaldi, Z. ve Riva, P. (2014) Experimental evaluation of the corrosion influence on the cyclic behaviour of RC columns, Engineering Structures, 76, 112-123. doi:10.1016/j.engstruct.2014.06.043

10. Rajput, A. S., Sharma, U. K. ve Engineer, K. (2019) Seismic retrofitting of corroded RC columns using advanced composite materials, Engineering Structures, 181, 35-46. doi:10.1016/j.engstruct.2018.12.009

11. Taşdemir, M. A., Özkul, M. H. ve Atahan, H. N. (1999) Türkiye'deki son depremler ve beton, II. Ulusal Kentsel Altyapı Sempozyumu, İMO, Adana, 9-19.

12. TS 708, (2016). Çelik - Betonarme için - Donatı çeliği, Türk Standartları Enstitüsü, Ankara.

13. TS EN 12390-3, (2019). Beton-Sertleşmiş beton deneyleri. Bölüm 3: Deney numunelerinde basınç dayanımının tayini, Türk Standartları Enstitüsü, Ankara.

14. TS EN 12390-6, (2010). Beton-Sertleşmiş beton deneyleri. Bölüm 6: Deney numunelerinin yarmada çekme dayanımının tayini, Türk Standartları Enstitüsü, Ankara.

15. TS EN 197-1, (2012). Çimento - Bölüm 1: Genel çimentolar - Bileşim, özellikler ve uygunluk kriterleri, Türk Standartları Enstitüsü, Ankara.

16. TS EN ISO 15630-1, (2019). Çelik - Betonarme ve ön gerilmeli beton için - Deney metotları - Bölüm 1: Donatı çubukları, halatı ve teli. Türk Standartları Enstitüsü, Ankara.

17. TS EN ISO 6892-1, (2020). Metalik malzemeler - Çekme deneyi - Bölüm 1: Ortam sıcaklığında deney yöntemi, Türk Standartları Enstitüsü, Ankara.

18. Yalçıner, H., Kumbasaroğlu, A. ve Ertuç, İ. (2018). Korozyon Etkisine Maruz Bırakılmış Betonarme Kirişlerin Eğilme Davranışı. Erzincan Üniversitesi Fen Bilimleri Enstitüsü Dergisi, 11 (1) , 1-10. doi:10.18185/erzifbed.359173

19. Yang, S. Y., Song, X. B., Jia, H. X., Chen, X. ve Liu, X. L. (2016) Experimental research on hysteretic behaviors of corroded reinforced concrete columns with different maximum amounts of corrosion of rebar, Construction and Building Materials, 121, 319-327. doi:10.1016/j.conbuildmat.2016.06.002 
